\title{
Innovative aspects of environmental chemistry and technology regarding air, water, and soil pollution
}

\author{
loannis A. Katsoyiannis ${ }^{1} \cdot$ Gerhard Lammel $^{2,3} \cdot$ Constantini Samara $^{4} \cdot$ Mathias Ernst $^{5}$ - Jannis Wenk ${ }^{6}$. \\ Vincenzo Torretta ${ }^{7}$. Dimitra Voutsa ${ }^{2}$. Jes Vollertsen ${ }^{8}$. Thomas D. Bucheli ${ }^{9} \cdot$ Levke Godbersen $^{9}$. \\ Dimitra Lambropoulou ${ }^{2,10}$. Ester Heath ${ }^{11} \cdot$ Roland Kallenborn $^{12} \cdot$ Dimitrios Giannakoudakis $^{13}$. Eleni Deliyanni ${ }^{1}$. \\ Teresa J. Bandosz ${ }^{14}$. Slavica Ražić ${ }^{15}$ • Viktoria Samanidou ${ }^{16} \cdot$ Ester Papa $^{7}$. Silvia Lacorte ${ }^{17} \cdot$ Athanasios Katsoyiannis $^{18}$
}

Published online: 9 September 2021

(C) The Author(s), under exclusive licence to Springer-Verlag GmbH Germany, part of Springer Nature 2021

The 17th International Conference on Chemistry and the Environment (ICCE 2019) took place in the period 16-20 June 2019, in Thessaloniki, Greece. The Conference Centre of the Aristotle University of Thessaloniki, named KEDEA, was chosen as an appropriate venue for the conference. Through its lecture halls, foyer for posters and exhibition stands, food, and refreshment facilities, it offered a great conference environment. We appreciate the help of all people involved in the efficient and smooth organization (Organizing Committee, University personnel, Students) of ICCE 2019. The ICCE has been organized since 1980 by the Division of Chemistry and the Environment (DCE) of the European Chemical Society (EuChemS) as a biennial conference. The first meeting took place in Paris.

ICCE 2019 was officially hosted by the Association of Greek Chemists, regional branch of Central and Western Macedonia. The Chair of the conference was Professor Ioannis Katsoyiannis (Aristotle University of Thessaloniki). Thirty-six scientists from 23 countries comprised the members of the scientific committee and played a very active role in organizing the sessions and satellite events (Table 1).

The conference was held under the auspices of the President of the Hellenic Republic, Professor Prokopios Pavlopoulos. It was opened by Professor Athanasios Papadopoulos, the President of the Association of Greek Chemists and Professor Philippe Guarrigues, the Editor in Chief of the journal Environmental Science and Pollution

Responsible Editor: Philippe Garrigues

Ioannis A. Katsoyiannis katsogia@chem.auth.gr

Extended author information available on the last page of the article
Research. Professor Ioannis Katsoyiannis, the Chairman of the Conference and of Division of Chemistry and Environment of the European Chemical Society, welcomed the delegates during the opening ceremony.

Professor Constantini Samara, from the Department of Chemistry of Aristotle University of Thessaloniki, Greece, delivered the opening lecture on air pollution entitled: "Key insights into the in vitro toxicity of airborne particulate matter in urban areas - The involvement of residential wood burning." During the five-day program, four additional plenary lectures were delivered by highly reputable experts as follows:

- Silvia Lacorte, Professor IDAEA SIC, Barcelona, Spain: The intriguing link between chemical exposure and biological effects.

- Urs von Gunten, Professor EPFL and EAWAG, Switzerland: Oxidative processes for Water treatment: Are we on track?

- Mathias Ernst, Professor, Technical University of Hamburg, Germany: Impact of natural organic matter (NOM) on $\mathrm{CaSO}_{4}$ crystallisation in the reverse osmosis process.

- Roland Kallenborn, Professor, Norwegian University of Life Sciences and University Center in Svalbard, Norway: Organic environmental pollutants as quality indicators and sentinels for circular bioeconomy and development of sustainable energy resources.

More than 500 participants from 70 countries attended the conference. The program included a total of 295 oral and 230 poster presentations. The conference consisted of 19 different topics, covering a wide range of environmental chemistry and technology. Water scarcity and reuse, air pollution issues, the presence of micro-plastics and micro-pollutants in waters, 
Table 1 Members of the scientific committee of the ICCE 2019 and country of workplace

\begin{tabular}{ll}
\hline Patrik Andersson, Sweden & Ioannis Katsoyiannis, Greece \\
Thomas Bucheli, Switzerland & Silvia Lacorte, Spain \\
Boguslaw Buzsewski, Poland & Mathias Ernst, Germany \\
George Cobb, USA & Dimitra Lambropoulou, Greece \\
Adrian Covaci, Belgium & Gerhard Lammel, Germany \\
Willem de Lange, Netherlands & Maria Eduarda Pereira, Portugal \\
Eleni Deliyanni, Greece & Santiago V. Luis, Spain \\
Dion Dionysiou, USA & Antonio Marcomini, Italy \\
Fritz Frimmel, Germany & Costas Michael, Cyprus \\
Philippe Garrigues, France & Nicolas Moussiopoulos, Greece \\
Walter Giger, Switzerland & Valery Petrosyan, Russia \\
Vincenzo Torretta, Italy & Aleksander Sabljic, Croatia \\
Ester Heath, Slovenia & Constantini Samara, Greece \\
Sirpa Herve, Finland & Michaela Dina Stănescu, Romania \\
Ivana Ivancev-Tumbas, Serbia & Dimitra Voutsa, Greece \\
Roland Kallenborn, Norway & Uri Zoller, Israel \\
Athanasios Katsoyiannis, Italy & Kostas Triantafyllidis, Greece \\
Jan Tř́ska, Czech Republic & Abel Maharramov, Azerbaijan \\
\hline
\end{tabular}

circular economy and resource recovery, and the consequences of widespread use of glyphosate were some of the topics analyzed by prominent scientists. The session on Analytical Chemistry in Environmental Monitoring and Chemistry Studies comprised an interaction with the EuChemS Division of Analytical Chemistry, and the session on Green and Sustainable Chemistry Strategies for Agricultural and Food Waste Biomass Valorizations with the EuChemS Division of Green and Sustainable Chemistry. The session Environmental Problems Relevant to Mediterranean Sea and Gulf of Mexico (MedSea-GuMex) was a collaborative effort with the Division of Environmental Chemistry of the American Chemical Society.

The sessions were introduced by 27 invited key note speakers and covered a variety of subjects as shown in Table 2.

On Sunday and Thursday, 5 satellite events were organized as shown in Table 3.

ICCE 2019 provided a solid base for a professional knowledge exchange, inspiration, and networking through the highlevel scientific program with both oral and poster presentations. During the opening session of ICCE 2019, Professor

Table 2 List of sessions, conveners, and keynote speakers

\begin{tabular}{|c|c|c|c|}
\hline & Session title & Conveners & Key note speakers \\
\hline 1 & Air pollution - chemistry and health risks & $\begin{array}{l}\text { G. Lammel, C. } \\
\text { Samara }\end{array}$ & $\begin{array}{l}\text { Gerhard Lammel, Masaryk University, Czech Republic, and } \\
\text { Max Planck Institute for Chemistry, Mainz, Germany }\end{array}$ \\
\hline 2 & $\begin{array}{l}\text { Oxidation and Advanced Oxidation processes in water and } \\
\text { wastewater treatment }\end{array}$ & $\begin{array}{l}\text { U. von Gunten, J. } \\
\text { Wenk }\end{array}$ & $\begin{array}{l}\text { Peter Tentscher, Aalborg University, Denmark; Dionysios } \\
\text { Dionyisiou, University of Cincinnati, USA }\end{array}$ \\
\hline 3 & $\begin{array}{l}\text { Recycling and resource reuse as tools for efficient circular } \\
\text { economy }\end{array}$ & $\begin{array}{l}\text { R. Kallenborn, N. } \\
\text { Moussiopoulos }\end{array}$ & $\begin{array}{l}\text { K. Aravosis, NTUA, Greece; Petter Jenssen, Norwegian } \\
\text { University of Life Sciences, Norway }\end{array}$ \\
\hline 4 & Innovation in Drinking Water Treatment & $\begin{array}{l}\text { M. Ernst, I. } \\
\text { Katsoyiannis }\end{array}$ & $\begin{array}{l}\text { Frederik Zietzschmann, TU Delft, Nederlands; Stefan } \\
\text { Panglisch, University of Duisburg-Essen, Germany }\end{array}$ \\
\hline 5 & Soil Pollution and Monitoring & $\begin{array}{l}\text { T. D. Bucheli, D. } \\
\text { Wächter, L. } \\
\text { Godbersen }\end{array}$ & Andreas Schäffer, RWTH Aachen University, Germany \\
\hline 6 & $\begin{array}{l}\text { Humic Substances: environmental dynamics and impact on } \\
\text { water quality }\end{array}$ & $\begin{array}{l}\text { I. Deligiannakis, G. } \\
\text { Abbt-Braun }\end{array}$ & Gudrun Abbt-Braun, KIT, Germany \\
\hline 7 & $\begin{array}{l}\text { Investigating the environmental fate and ecotoxicology of } \\
\text { glyphosate }\end{array}$ & $\begin{array}{l}\text { L. McConnell, } \\
\text { E. Heath, }\end{array}$ & $\begin{array}{l}\text { Keith Solomon, University of Guelph, Canada; } \\
\text { Steven Levine, Bayer, USA; } \\
\text { Stephen O. Duke, USDA-ARS, USA }\end{array}$ \\
\hline 8 & $\begin{array}{l}\text { Recent advances in targeted and non-targeted screening } \\
\text { strategies based on high resolution accurate mass spec- } \\
\text { trometry in environmental and food analysis }\end{array}$ & $\begin{array}{l}\text { A. Covaci, D. } \\
\text { Lambropoulou, } \\
\text { E. Heath }\end{array}$ & Susan D. Richardson, University of South Carolina, USA \\
\hline 9 & $\begin{array}{l}\text { Urban contaminants: control measures, remediation actions } \\
\text { and toxicological implications }\end{array}$ & $\begin{array}{l}\text { S. Lacorte, A. } \\
\text { Katsoyiannis }\end{array}$ & Nuno Ratola, University of Porto, Portugal \\
\hline 10 & Micropollutants and microplastics in the aquatic environment & $\begin{array}{l}\text { D. Voutsa, S. } \\
\text { Wagner, J. } \\
\text { Vollertsen }\end{array}$ & Denise Mitrano, EAWAG, Switzerland \\
\hline 11 & $\begin{array}{l}\text { Environmental problems relevant to Mediterranean Sea and } \\
\text { Gulf of Mexico (MedSea-GuMex) }\end{array}$ & $\begin{array}{l}\text { G. Cobb, I. } \\
\text { Katsoyiannis }\end{array}$ & - \\
\hline 12 & Environmental fate of contaminants & U., Jans, F., Breider & - \\
\hline 13 & Environmental applications of nanomaterials & $\begin{array}{l}\text { E. Deliyanni, T.J. } \\
\text { Bandosz }\end{array}$ & $\begin{array}{l}\text { Teresa J. Bandosz, The City University of New York, USA; } \\
\text { Dimitris Giannakoudakis, Polish Academy of Sciences, } \\
\text { Poland }\end{array}$ \\
\hline
\end{tabular}


Table 2 (continued)

\begin{tabular}{|c|c|c|c|}
\hline & Session title & Conveners & Key note speakers \\
\hline 14 & $\begin{array}{l}\text { Heavy metals and other inorganic pollutants in the } \\
\text { environment and removal technologies }\end{array}$ & $\begin{array}{l}\text { G. Gallios, N.K. } \\
\text { Lazaridis }\end{array}$ & Eleni Deliyanni, Aristotle University of Thessaloniki, Greece \\
\hline 15 & Metabolomics & $\begin{array}{l}\text { B. Buzewski, R. } \\
\text { Tauler, G. } \\
\text { Theodoridis }\end{array}$ & $\begin{array}{l}\text { George Theodoridis, Aristotle University of Thessaloniki; } \\
\text { Greece Piotr Stepnowski, University of Gdansk, Poland; } \\
\text { Boguslaw Buszewski, Nicolaus Copernicus University, } \\
\text { Poland }\end{array}$ \\
\hline 16 & $\begin{array}{l}\text { Green and sustainable chemistry strategies for agricultural } \\
\text { and food waste biomass valorizations }\end{array}$ & $\begin{array}{l}\text { N. Gathergood, K. } \\
\text { Triantafyllidis, A. } \\
\text { Zabaniotou }\end{array}$ & $\begin{array}{l}\text { N. Gathergood, Tallinn University of Technology, Estonia; } \\
\text { Juan Carlos Colmenares, Polish Academy of Sciences, } \\
\text { Poland }\end{array}$ \\
\hline 17 & $\begin{array}{l}\text { Analytical Chemistry in environmental monitoring and } \\
\text { chemistry studies Interaction DCE - DAC }\end{array}$ & $\begin{array}{l}\text { V. Samanidou, S. } \\
\text { Ražić }\end{array}$ & Paul Worsfold, University of Plymouth, UK \\
\hline 18 & $\begin{array}{l}\text { Identifying critical nutrient emission zones in landscapes: a } \\
\text { key for reducing water eutrophication? }\end{array}$ & $\begin{array}{l}\text { M. Grybos, G. } \\
\text { Gruau }\end{array}$ & $\begin{array}{l}\text { Erwin Klumpp, Agrosphere, Jülich Research Centre, } \\
\text { Germany }\end{array}$ \\
\hline 19 & $\begin{array}{l}\text { Risk assessment of emerging pollutants experimental and } \\
\text { modelling approaches to fill the data gaps }\end{array}$ & $\begin{array}{l}\text { P. Andersson, E. } \\
\text { Papa }\end{array}$ & Ester Papa, University of Insubria, Italy \\
\hline 20 & Advances in wastewater treatment & $\begin{array}{l}\text { V. Torretta, G. } \\
\text { Bertanza, M. C. } \\
\text { Collivignarelli }\end{array}$ & Giorgio Bertanza, University of Brescia, Italy \\
\hline
\end{tabular}

emeritus Panagiotis Siskos, University of Athens, Greece, received the DCE Lifetime Achievement Award for his early and long-lasting contributions to environmental chemistry studies in the Mediterranean region and particularly in Greece and his services for the Division of Chemistry and Environment of the European Chemical Society.

The special issue dedicated to the conference contains 42 representative papers that are based on contributions to the ICCE 2019. The following topics are covered: air pollution
(Besis et al. 2020; Eivazzadeh et al. 2021; Franzin et al. $2021 \mathrm{a}$; Franzin et al. 2021b; Kaikiti et al. 2020; Karageorgou et al. 2020; Kitanovski et al. 2020; Kogianni et al. 2020; Liu et al. 2020; Pytel et al. 2020; Szewczyńska et al. 2020; Wei et al. 2021), environmental analytical chemistry (Buledi et al. 2020; Đurđić et al. 2020; Georgieva et al. 2020; Ivančev-Tumbas et al. 2020; Kalogiouri and Samanidou 2020; Manousi et al. 2020; Mlynek et al. 2020; Tsiasioti and Tzanavaras 2020; Tolosa et al. 2020)

Table 3 List of satellite events, conveners, and invited speakers

\begin{tabular}{|c|c|c|}
\hline Topic & Conveners & Invited speakers \\
\hline $\begin{array}{l}\text { Water reuse as a secure path to } \\
\text { tackle water scarcity }\end{array}$ & $\begin{array}{l}\text { Conveners: D. Dionysiou, University of Cincinnati, } \\
\text { USA; } \\
\text { I. Katsoyiannis, Aristotle University of Thessaloniki, } \\
\text { Greece }\end{array}$ & $\begin{array}{l}\text { D. Dionysiou, University of Cincinnati, USA; } \\
\text { B. Gawlik, European Commission; } \\
\text { R. Elelman, Head of Public Administrations of } \\
\text { EURECAT-CTM; } \\
\text { Simos Malamis, National Technical University of } \\
\text { Athens, Greece }\end{array}$ \\
\hline $\begin{array}{l}\text { Multi-residue analysis of modern } \\
\text { pesticides in soil }\end{array}$ & $\begin{array}{l}\text { T. D. Bucheli, Agroscope, Switzerland; E. Karassali, } \\
\text { Benaki Phytopathological Institute, Greece; D. } \\
\text { Wächter, Swiss Soil Monitoring Network, Switzerland }\end{array}$ & $\begin{array}{l}\text { S. Magnold, Agroscope Switzerland; T.D. Bucheli, } \\
\text { Agroscope, Switzerland; L. Godbersen, D. Wächter, } \\
\text { Agroscope Switzerland }\end{array}$ \\
\hline Glyphosate & $\begin{array}{l}\text { S. Lacorte, IDAEA-CSIC, Barcelona, Spain; } \\
\text { L. McConnell, Bayer Crop Science, Durham, North } \\
\text { Carolina, USA; } \\
\text { E. Heath, Jožef Stefan Institute, Ljubljana, Slovenia }\end{array}$ & $\begin{array}{l}\text { S. O. Duke,University, Mississippi, USA; } \\
\text { J. Oriol Magrans, EFSA, Parma, Italy; } \\
\text { K. Solomon, University of Guelph, Canada; } \\
\text { S. Levine, Bayer, St. Louis, Missouri, USA; } \\
\text { E. J. González Sánchez, University of Cordoba, Spain }\end{array}$ \\
\hline $\begin{array}{l}\text { University Education in } \\
\text { Environmental Sciences } \\
\text { (Ivančev-Tumbas and Lammel } \\
\text { 2020) }\end{array}$ & $\begin{array}{l}\text { I.Ivančev-Tumbas, University of Novi Sad, Serbia; } \\
\text { G. Lammel, Max Planck Institute for Chemistry, Mainz, } \\
\text { Germany, Masaryk University, Brno, Czech Republic }\end{array}$ & $\begin{array}{l}\text { C. Zwiener, University of Tübingen, Germany; P. } \\
\text { Andersson, Umeå University, Sweden; I. } \\
\text { Ivančev-Tumbas, University of Novi Sad, Serbia }\end{array}$ \\
\hline Scientific writing and publishing & $\begin{array}{l}\text { P. Garrigues, Université Bordeaux, France, Editor in } \\
\text { Chief, Environmental Science and Pollution Research }\end{array}$ & $\begin{array}{l}\text { P. Garrigues, Université Bordeaux, France, Editor in } \\
\text { Chief, Environmental Science and Pollution Research }\end{array}$ \\
\hline
\end{tabular}


micropollutants in the environment (Damikouka and Katsiri 2020; Đurkić et al. 2020; Pittroff et al. 2021; Ricci et al. 2020; Tubić et al. 2021 ) urban contaminants (Bhanot and Hundal 2020; Cristale et al. 2020; Dalmau-Soler et al. 2021; Nélieu et al. 2020), recycling and resource recovery (Charitopoulou et al. 2020; Halbert-Howard et al. 2020; Jovanovic et al. 2020; Mikoda et al. 2020; Rada et al. 2020; Rekos et al. 2020), risk assessment (Molnar et al. 2020; Svigruha et al. 2020), soil pollution and monitoring (Porto et al. 2020), and water treatment (Collivignarelli et al. 2021; Geczo et al. 2020; Usman et al. 2020).

The 18th ICCE will take place in Venice in 2023 and will be organized by the Association of Italian Chemists in cooperation with the DCE. The local organizing committee will be chaired by Professor Antonio Marcomini, University $\mathrm{Ca}$ ' Foscari, Venice, Italy.

\section{References}

Besis A, Latsios I, Papakosta E, Simeonidis T, Kouras A, Voliotis A, Samara C (2020) Spatiotemporal variation of odor-active VOCs in Thessaloniki. Greece: implications for impacts from industrial activities Environ Sci Pollut Res. https://doi.org/10.1007/s11356-02008573-y

Bhanot R, Hundal SS (2020) Assessment of cytotoxicity in gills of fish Labeo rohita reared in untreated and treated sewage water. Environ Sci Pollut Res. https://doi.org/10.1007/s11356-020-10619-0

Buledi JA, Amin S, Haider SI, Bhanger MI, Solangi AR (2020) A review on detection of heavy metals from aqueous media using nanomaterial-based sensors. Environ Sci Pollut Res. https://doi. org/10.1007/s11356-020-07865-7

Charitopoulou MA, Kalogiannis KG, Lappas AA, Achilias DS (2020) Novel trends in the thermo-chemical recycling of plastics from WEEE containing brominated flame retardants. Environ Sci Pollut Res. https://doi.org/10.1007/s11356-020-09932-5

Collivignarelli MC, Abbà A, Carnevale Miino M, Bertanza G, Sorlini S, Damiani S, Arab H, Bestetti M, Franz S (2021) Photoelectrocatalysis on $\mathrm{TiO} 2$ meshes: different applications in the integrated urban water management. Environ Sci Pollut Res. https:// doi.org/10.1007/s11356-021-12606-5

Cristale J, Oliveira Santos I, Umbuzeiro G et al (2020) Occurrence and risk assessment of organophosphate esters in urban rivers from Piracicaba watershed (Brazil). Environ Sci Pollut Res. https://doi. org/10.1007/s11356-020-10150-2

Dalmau-Soler J, Ballesteros-Cano R, Boleda MR, Paraira M, Ferrer N, Lacorte S (2021) Microplastics from headwaters to tap water: occurrence and removal in a drinking water treatment plant in Barcelona Metropolitan area (Catalonia, NE Spain). Environ Sci Pollut Res. https://doi.org/10.1007/s11356-021-13220-1

Damikouka I, Katsiri A (2020) Natural attenuation in marine sediments: investigation of the effect of chloride concentration on the mobility of metals. Environ Sci Pollut Res. https://doi.org/10.1007/s11356020-09852-4

Đurđić S, Stanković V, Ražić S et al (2020) Lead isotope ratios as tool for elucidation of chemical environment in a system of Macrolepiota procera (Scop.) Singer - soil. Environ Sci Pollut Res. https://doi.org/ 10.1007/s11356-020-07947-6
Đurkić T, Molnar Jazić J, Watson M, Bašić B, Prica M, Tubić A, Maletić S, Agbaba J (2020) Application of UV-activated persulfate and peroxymonosulfate processes for the degradation of 1,2,3trichlorobenzene in different water matrices. Environ Sci Pollut Res. https://doi.org/10.1007/s11356-020-09787-w

Eivazzadeh M, Hassanvand MS, Faridi S, Gholampour A (2021) Source apportionment and deposition of dustfall-bound trace elements around Tabriz. Iran Environ Sci Pollut Res. https://doi.org/10. 1007/s11356-020-12173-1

Franzin BT, Hojo O, Ferreira MR, Forti MC, Meneghetti CD, de Marchi MRR, de Oliveira CMRR, Fertonani FL (2021a) Low-cost Gent type sampler constructed for urban atmospheric aerosol sampling. Environ Sci Pollut Res. https://doi.org/10.1007/s11356-020-121031

Franzin BT, Guizellini FC, Hojo O et al (2021b) Chemical and morphostructural characterization of atmospheric aerosol (PM10 and PM2.5) in a city of São Paulo state, Brazil. Environ Sci Pollut Res. https://doi.org/10.1007/s11356-021-13602-5

Geczo A, Giannakoudakis DA, Triantafyllidis K, Elshaer MR, Rodríguez-Aguado E, Bashkova S (2020) Mechanistic insights into acetaminophen removal on cashew nut shell biomass-derived activated carbons. Environ Sci Pollut Res. https://doi.org/10.1007/ s11356-019-07562-0

Georgieva SK, Georgieva A, Peteva Z, Dimova D (2020) Trace elements in commonly used medicinal plants from Varna region. Bulgaria Environ Sci Pollut Res. https://doi.org/10.1007/s11356-02010463-2

Halbert-Howard A, Häfner F, Karlowsky S, Schwarz D, Krause A (2020) Evaluating recycling fertilizers for tomato cultivation in hydroponics, and their impact on greenhouse gas emissions. Environ Sci Pollut Res. https://doi.org/10.1007/s11356-020-10461-4

Ivančev-Tumbas I, Lammel G (2020) 17th ICCE Satellite Event University Education in Environmental Sciences. Environ Sci Pollut Res. https://doi.org/10.1007/s11356-020-10809-w

Ivančev-Tumbas I, Lužanin Z, Česen M, Bogunović M, Sekulić TD, Heath D, Heath E (2020) Insight into selected emerging micropollutant interactions with wastewater colloidal organic carbon: implications for water treatment and analysis. Environ Sci Pollut Res. https://doi.org/10.1007/s11356-020-11309-7

Jovanovic JD, Petkovic SD, Gigov MN, Adnadjevic BK (2020) Extractive desulfurization of pyrolysis tire oil with deep eutectic solvent using hydrodynamic cavitation. Environ Sci Pollut Res. https://doi.org/10.1007/s11356-020-10435-6

Kaikiti K, Stylianou M, Agapiou A (2020) Use of biochar for the sorption of volatile organic compounds (VOCs) emitted from cattle manure. Environ Sci Pollut Res. https://doi.org/10.1007/s11356-020-09545y

Kalogiouri NP, Samanidou VF (2020) Liquid chromatographic methods coupled to chemometrics: a short review to present the key workflow for the investigation of wine phenolic composition as it is affected by environmental factors. Environ Sci Pollut Res. https:// doi.org/10.1007/s11356-020-09681-5

Karageorgou K, Manoli E, Kouras A, Samara C (2020) Commuter exposure to particle-bound polycyclic aromatic hydrocarbons in Thessaloniki. Greece Environ Sci Pollut Res. https://doi.org/10. 1007/s11356-020-09475-9

Kitanovski Z, Hovorka J, Kuta J, Leoni C, Prokeš R, Sáňka O, Shahpoury P, Lammel G (2020) Nitrated monoaromatic hydrocarbons (nitrophenols, nitrocatechols, nitrosalicylic acids) in ambient air: levels, mass size distributions and inhalation bioaccessibility. Environ Sci Pollut Res. https://doi.org/10.1007/s11356-02009540-3

Kogianni E, Kouras A, Samara C (2020) Indoor concentrations of PM2.5 and associated water-soluble and labile heavy metal fractions in workplaces: implications for inhalation health risk assessment. 
Environ Sci Pollut Res. https://doi.org/10.1007/s11356-019-075848

Liu X, Jiang N, Zhang R et al (2020) Composition analysis of PM2.5 at multiple sites in Zhengzhou, China: implications for characterization and source apportionment at different pollution levels. Environ Sci Pollut Res. https://doi.org/10.1007/s11356-020-10943-5

Manousi N, Zachariadis GA, Deliyanni EA (2020) On the use of metalorganic frameworks for the extraction of organic compounds from environmental samples. Environ Sci Pollut Res. https://oi.org/10. 1007/s11356-020-07911-4

Mikoda B, Potysz A, Gruszecka-Kosowska A, Kmiecik E, Tomczyk A (2020) Spent sulfuric acid plant catalyst: valuable resource of vanadium or risky residue? Process comparison for environmental implications. Environ Sci Pollut Res. https://doi.org/10.1007/s11356$020-11349-Z$

Mlynek F, Himmelsbach M, Buchberger W, Klampfl CW (2020) Time study on the uptake of four different beta-blockers in garden cress (Lepidium sativum) as a model plant. Environ Sci Pollut Res. https://doi.org/10.1007/s11356-020-11610-5

Molnar E, Maasz G, Pirger Z (2020) Environmental risk assessment of pharmaceuticals at a seasonal holiday destination in the largest freshwater shallow lake in Central Europe. Environ Sci Pollut Res. https://doi.org/10.1007/s11356-020-09747-4

Nélieu S, Lamy I, Karolak S, Delarue G, Crouzet O, Barraud C, Bimbot M, Allaoui F, Hanot C, Delorme A, Lévi Y, Hulot FD, Baudry E (2020) Impact of peri-urban landscape on the organic and mineral contamination of pond waters and related risk assessment. Environ Sci Pollut Res. https://doi.org/10.1007/s11356-020-10355-5

Pittroff M, Müller YK, Witzig CS, Scheurer M, Storck FR, Zumbülte N (2021) Microplastic analysis in drinking water based on fractionated filtration sampling and Raman microspectroscopy. Environ Sci Pollut Res. https://doi.org/10.1007/s11356-021-12467-y

Porto RS, Pinheiro RSB, Rath S (2020) Leaching of benzimidazole antiparasitics in soil columns and in soil columns amended with sheep excreta. Environ Sci Pollut Res. https://doi.org/10.1007/s11356020-08389-w

Pytel K, Marcinkowska R, Zabiegała B (2020) Investigation on air quality of specific indoor environments - spa salons located in Gdynia Poland. Environ Sci Pollut Res. https://doi.org/10.1007/s11356020-09860-4

Rada EC, Ionescu G, Ferronato N, Ragazzi M, Raspanti M, Conti F, Torretta V (2020) Zooming on light packaging waste differences by scanning electron microscopy. Environ Sci Pollut Res. https:// doi.org/10.1007/s11356-020-08414-y

Rekos K, Kampouraki ZC, Panou C, Baspanelou A, Triantafyllidis K, Deliyanni E (2020) Adsorption of DBT and 4,6-DMDBTon nanoporous activated carbons: the role of surface chemistry and the solvent. Environ Sci Pollut Res. https://doi.org/10.1007/ s11356-020-08242-0

Ricci M, Shegunova P, Vorkamp K (2020) State of the art in the analysis of brominated flame retardants in biota and sediment: insights from the characterisation of two new certified reference materials. Environ Sci Pollut Res. https://doi.org/10.1007/s11356-02008950-7

Svigruha R, Fodor I, Padisak J, Pirger Z (2020) Progestogen-induced alterations and their ecological relevance in different embryonic and adult behaviours of an invertebrate model species, the great pond snail (Lymnaea stagnalis). Environ Sci Pollut Res. https:// doi.org/10.1007/s11356-020-12094-z

Szewczyńska M, Dobrzyńska E, Pośniak M (2020) Determination of phthalates in particulate matter and gaseous phase emitted in indoor air of offices. Environ Sci Pollut Res. https://doi.org/10.1007/ s11356-020-10195-3

Tolosa I, Huertas D, Choyke S, Sander S, Aminot Y (2020) A comprehensive evaluation of two sample treatment procedures for the determination of emerging and historical halogenated flame retardants in biota. Environ Sci Pollut Res. https://doi.org/10.1007/s11356020-10966-y

Tsiasioti A, Tzanavaras PD (2020) Automated fluorimetric sensor for hydrazine determination in water samples based on the concept of zone fluidics. Environ Sci Pollut Res. https://doi.org/10.1007/ s11356-020-08979-8

Tubić A, Lončarski M, Apostolović T, Kragulj Isakovski M, Tričković J, Molnar Jazić J, Agbaba J (2021) Adsorption mechanisms of chlorobenzenes and trifluralin on primary polyethylene microplastics in the aquatic environment. Environ Sci Pollut Res. https://doi.org/10. 1007/s11356-020-11875-w

Usman M, Katsoyiannis I, Rodrigues JH, Ernst M (2020) Arsenate removal from drinking water using by-products from conventional iron oxyhydroxides production as adsorbents coupled with submerged microfiltration unit. Environ Sci Pollut Res. https://doi.org/ 10.1007/s11356-020-08327-w

Wei J, Liu Y, Wang L, Sun X (2021) Research on evaluation of manufacturing cloud service oriented to environmental benefits of supply chain. Environ Sci Pollut Res. https://doi.org/10.1007/ s11356-021-13427-2

Publisher's note Springer Nature remains neutral with regard to jurisdictional claims in published maps and institutional affiliations.

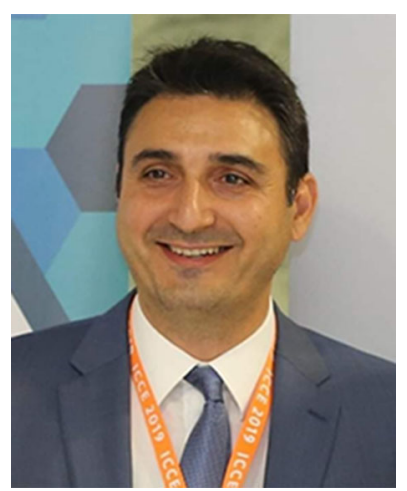

Prof. Ioannis Katsoyiannis is Associate Professor of Environmental Technology at the department of Chemistry of Aristotle University of Thessaloniki. Professor Katsoyiannis is currently serving as vice president of the Association of Greek Chemists, member of the Executive board of the European Chemical Society (EuChemS), Chair of the division of Chemistry and Environment of EuChemS, and editor for the journal Environmental Science and Pollution Research (Springer). He was the chair of the 17th International Conference on Chemistry and the Environment, ICCE 2019, which is the official environmental conference of the European Chemical Society (EuChemS). He is the President of the Hellenic Industrial Property Academy and member of the administrative council of the Hellenic Industrial Property Organization. He was recipient of prestigious international fellowships, such as from Alexander von Humboldt Foundation, German Academic Exchange Service (DAAD), the Swiss Science National Foundation, and Marie Curie Intra European Individual. He has conducted research at the Technical University of Berlin, Technical University of Hamburg, the ETH Zurich, and the EPFL. Between 2008 and 2014 he has worked as principal chemical engineer for the giant engineering companies Alstom Power and Hitachi Power Europe in the design, construction, and commissioning of some of the biggest thermal and combined cycle power plants in Europe. He has authored or co-authored more than 70 research papers in the fields of water treatment, water quality, and solid waste management, which have received to date more than 3400 citations with an $\mathrm{H}$ index of 31 (Scopus). He was invited more than 25 times to give lectures worldwide in international conferences and advanced schools. In 2020, he was included in the top $2 \%$ of scientists in the field of Environmental Technology (career-2019, as well as single year 2019), a list which was published in PLOS Biology based on data retrieved from SCOPUS. 


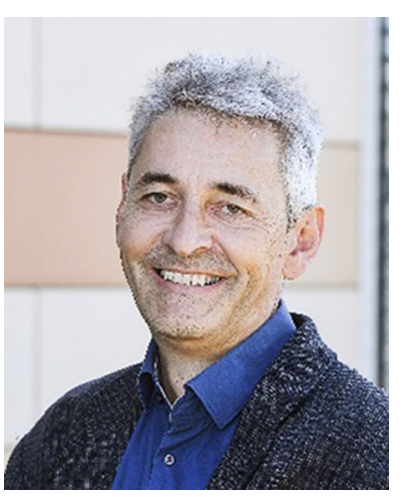

Prof. Gerhard Lammel graduated in Chemistry in 1985 (U Freiburg, Germany), got his $\mathrm{PhD}$ in Physical Chemistry (Max Planck Institute for Chemistry/U Mainz, Germany) in 1988, and his habilitation in Environmental Chemistry (U Hohenheim, Stuttgart, Germany) in 2000. He became a full professor at Masaryk University (MU), Brno, Czech Republic, in 2007. His research, pursued at Karlsruhe Institute of Technology, Lawrence Berkeley National Laboratory, Max Planck Institute for Meteorology, Hamburg, University of Hamburg; MU's Research Centre for Toxic Compounds in the Environment (since 2006); and Max Planck Institute for Chemistry (since 2008), has been focusing on atmospheric aerosols and on total environmental (multi-compartmental) chemistry of organic pollutants, based on field experiments and advanced numerical modeling. He has authored $130+$ research papers (h-index 32 ) and contributed to a number of scientific assessment reports (UNEP, AMAP, IPCC, WHO, UNECE, German Advisory Council on Global Change). He was Chair of the Board of the German Chemical Society's Division of Environmental Chemistry and Ecotoxicology, is Member of the European Chemical Societies' Division of Chemistry and the Environment, and an associate editor of ESPR.

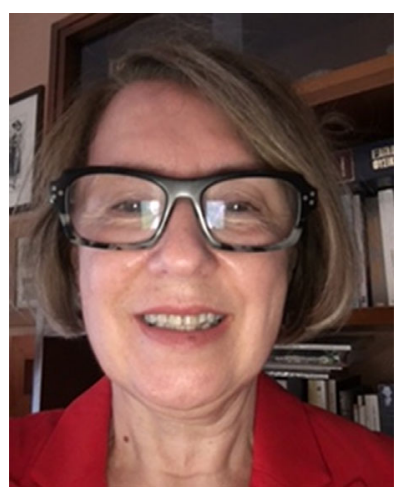

Prof. Constantini Samara graduated in Chemistry in 1977 from the Aristotle University of Thessaloniki, Greece, and received her $\mathrm{PhD}$ in Environmental Chemistry in 1985 by the same university. She became a full professor at the Department of Chemistry of the Aristotle University of Thessaloniki, Environmental Pollution Control Laboratory, in 2010. Since then, she has been Head of the Atmospheric Particles Measurements Team (APMTeam), that is accredited according to ELOT EN ISO/IEC 17025:2017for the measurement of PM10/PM2.5 in the ambient air. Her recent research has been focusing on the occurrence and environmental fate of health relevant organic pollutants in the ambient air ( $\mathrm{g} / \mathrm{p}$ partitioning, size distribution, wet-dry deposition) and in indoor microenvironments, human exposure and health risk assessment, toxicological characterization of ambient PM, and indoor dust (redox activity). She has coordinated more than 60 research projects funded by national and European organizations. She has authored/co-authored $150+$ peer-reviewed publications in international journals, having more than 8000 citations from other investigators in the last 15 years and h-index 47. Since 2010, she has been editor of ESPR (Atmospheric Processes and Air Pollution).

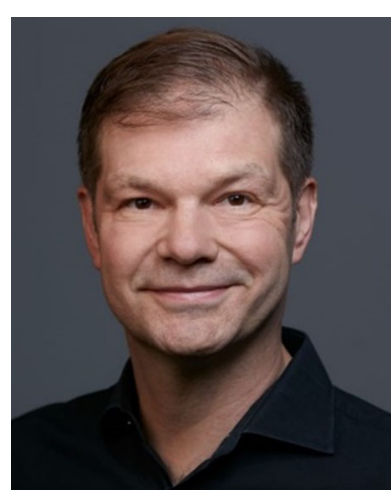

Prof. Mathias Ernst (H-index: 28) got his $\mathrm{PhD}$ in Environmental Engineering at TU Berlin, Germany, in the research group of Prof. Jekel (Department of Water Quality Control) in 1999. Within a Sino-German Cooperation Project with Tsinghua University, Beijing, the focus of his dissertation was on potable reuse technologies (nanofiltration, ozonation, groundwater recharge) of municipal wastewater. From 2001 to 2003 Dr. Ernst did his EU-MarieCurie-Industrial Host Fellowship with Vivendi Water (now Veolia Water) in the R\&D Centre MaisonsLaffitte near Paris. Here he studied and developed a catalytic oxidation process for industrial effluents. The new technology applying heterogeneous catalyst material was patented. After returning to Germany in 2004, Dr. Ernst was appointed as an Executive Manager and Associated Professor at the TU Berlin Centre for Water in Urban Areas. The Centre consisted of 14 research groups focused on water related engineering (Prof. Jekel, Prof. Kraume, Prof. Tröger, Prof. Hegeman, Prof. Wiesmann, etc.). In addition to teaching, Dr. Ernst was involved in many international research projects (Germany-Israel water technology, EU-FP7, industrial funds Taiwan, Sino-German funds, etc.) on water quality control until 2011. During this time, he was frequently invited at Tsinghua University as guest lecturer. In April 2012, Dr. Ernst was appointed as Chair of Institute of Water resources and Water Supply at Technical University Hamburg (https://www.tu-harburg.de/wwv/startseite.html). Adjunct to the Institute, he heads a local research branch of the German Association of Water and Gas (DVGW). Dr. Ernst is author and co-author of 63 scientific publications (http://orcid.org/0000-0001-9282-6683); he is member of the DVGW, the GDCh specialist group on water chemistry and the IWA, where he is currently a committee member of the specialised group on Membrane Technology.

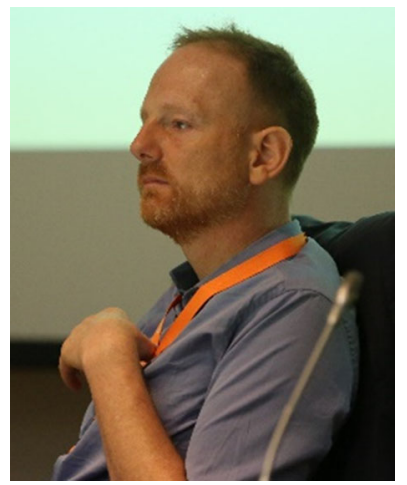

Dr. Jannis Wenk is a Senior Lecturer (Associate Professor) in Water Science and Engineering at University of Bath, UK. He is trained as an environmental engineer (Dipl.-Ing.) at TU Berlin (2008) and holds a $\mathrm{PhD}$ in environmental sciences (2013) from ETH Zurich conducted with Dr. Silvio Canonica and Prof. Urs von Gunten at Eawag, Switzerland. Before he joined the University of Bath as a Lecturer (Assistant Professor) in 2015, he worked as a postdoctoral fellow for two years at UC Berkeley and ReNUWIt Engineering Research Centre, USA, in the group of Prof. Kara Nelson and Prof. David Sedlak, funded a by Swiss National Science Foundation fellowship. Dr. Wenk's research focuses on water treatment process engineering for drinking water, water recycling, and wastewater treatment, specifically oxidative water treatment via ozonation and nature-oriented water treatment, such as constructed wetlands. He has also special interest in environmental photochemistry and published highly cited papers on the interaction of sunlight with both aquatic contaminants and pathogens. Dr. Wenk has published 34 peerreviewed research papers (1394 citations; H-index 14). For his research, Dr. Wenk has received funding from NERC, EPSRC, GCRF (Research 
England), The Royal Society, and Newton Fund. Recent awards include an Outstanding Reviewer award for "Water Research" in 2019 and a nomination at the IChemE Global Awards (Water) in 2018

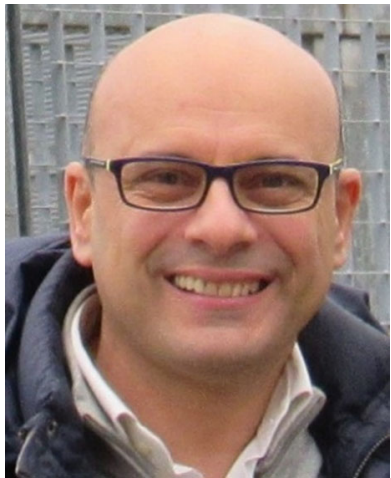

Dr. Vincenzo Torretta is a Full Professor, from 2020, of "Relevant Accident and Risk Assessment" and "Environmental Impact Assessments" at MSc. Course of Engineering for Safety and Environment and "Advanced Environmental Engineering" in the Master of Environmental and Workplace Sustainability Engineering, University of Insubria, Varese Italy. He is President of Engineering MSc. Course and Master, and member of the doctoral committee on Chemical and Environmental Sciences. Author of several papers published on environmental and safety engineering technical journals and author of books titled "Sicurezza e analisi di rischio di incidenti rilevanti" (Safety and Relevant Accident Risk Assessment) published by Sistemi Editoriali (2006), "Studi e procedure di valutazione di impatto ambientale" (Studies and Environmental Impact Assessment) by Flaccovio Editore (2010), "Ingegneria Sanitaria Ambientale" (Environmental Engineering) by Flaccovio Editore (2015), and "Valutazione e impatto ambientale Manuale tecnico-operativo per la elaborazione di studi di impatto ambientale" (Environmental Impact Assessment - Technical manual for the elaboration of Enviromental Impact Studies) by Hoepli Editore (2016). The research activity regards the following: energy recovery from biomass and waste, treatment of waste gas though chemical-physical and biological processes, environmental modeling and safety modeling, new technologies for treating wastewater, reuse of materials from solid waste, management and treatment of solid waste.

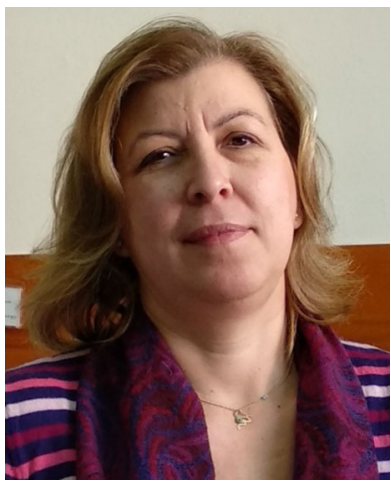

Dr. Dimitra Voutsa (H-index: 39) is a Full Professor of Environmental Chemistry in School of Chemistry of Aristotle University, Thessaloniki, Greece. She is currently Head of Environmental Pollution Control Laboratory. She received her $\mathrm{PhD}$ in Chemistry from Aristotle University. She carried out a postdoc research in Swiss Federal Institute of Aquatic Science and Technology, Zurich. Dr. D. Voutsa has developed research activities on various topics of environmental chemistry, pollution, and technology: (a) occurrence and fate of organic and inorganic pollutants in environment and technical systems; (b) drinking water quality, water treatment, and regulated and emerging disinfection by-products; (c) methods for removal micropollutants; and (d) chemical characterization of airborne atmospheric particles. Dr. D. Voutsa has authored and co-authored 95 research articles and reviews in international peer-reviewed scientific journals and chapters in books with more than 5400 citations. She has participated (as scientific responsible and as member of research team) in more than 50 research projects. She is member of the advisory board in the scientific journal Environmental
Science Europe. She has also participated in many scientific committees aiming at the critical evaluation of various environmental issues.

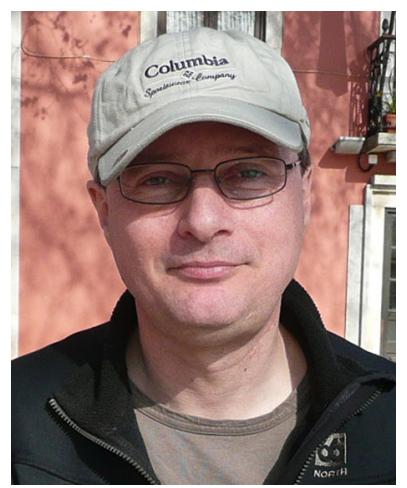

Jes Vollertsen is Professor of Environmental Engineering at Aalborg University, Denmark. His background is biological and chemical processes and pollutants in urban technical waters. He and his microplastics research group focus on analytical methods for quantification with the goal to contribute to trustworthy, fast, and affordable methods to quantify microplastics in the environment. The work targets all types of matrixes, e.g., water, wastewater, sludge, biosolids, sediments, soil, biota, food, and air. His goal is to quantify sources and occurrence of environmental microplastics and address the processes behind mitigation technologies. He addresses aspects of the physical, chemical, and biological breakdown of microplastics in the environment.

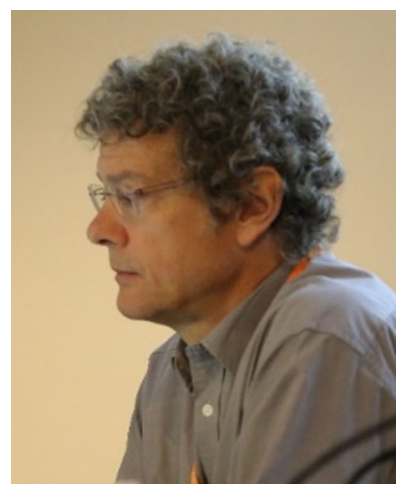

Dr. Thomas D. Bucheli , Ph.D., leads the research group Environmental Analytics at Agroscope, the Swiss Centre of Excellence for Agricultural Research, where he investigates the occurrence, fate, and behavior of organic chemicals in the agro-environment. His current focus is on natural toxins, pesticides, plastics, biochar, and related occurrence, sorption, and bioavailability studies. He is a lecturer at the Swiss Federal Institute of Technology and an Editor of ESPR.

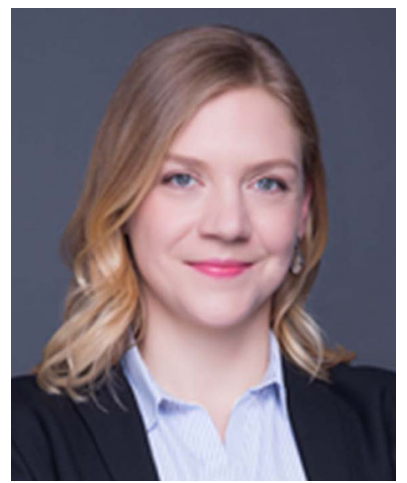

Levke Godbersen is a geographer by training and jack of many trades with a strong interest in behavior of chemical substances in the environment and product safety of agrochemical products. Lately, she is getting more and more into digitalization. During her career, she was lucky enough to gain experience in public service, academia and, most recently, corporate work settings in Germany, China, and Switzerland. 


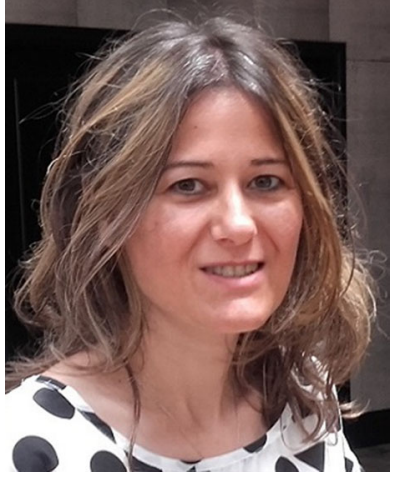

Dr. Dimitra Lambropoulou is currently Associate Professor of Environmental Chemistry in the Environmental Pollution Control Laboratory, Department of Chemistry, Aristotle University of Thessaloniki. She has published more than 140 scientific research papers in high-impact international peer-reviewed scientific journals and 14 chapters in scientific books that have received more than 6800 citations ( $h$ index 43). She has been participating in more than 50 national and European research projects. She was PI-investigator for a number of research project (20)-related to analysis, structure elucidation, monitoring, treatment, fate, and toxicity of organic micropollutants. She coordinates 9 Lifelong Learning Course at the Auth. She coedited two books focused on "Transformation Products of Emerging Contaminants in the Environment and Chromatographic Analysis by Mass Spectrometry." Her main research interests are the development and application of novel sample preparation techniques coupled to advanced mass spectrometry approaches in the field of environmental chemistry; design and application of new materials in analytical and separation sciences; occurrence, transport, fate, and effects of emerging contaminants in the environment; environmental and food safety; identification and structure elucidation of organic contaminants by high-resolution mass spectrometry; and application of "omics" techniques to environmental problems. She is also interested in the development of effective degradation and purification processes for the mineralization of organic micropollutants such as advanced oxidation processes (AOPs). She serves as Associate Editor for the journal Science of Total Environment.

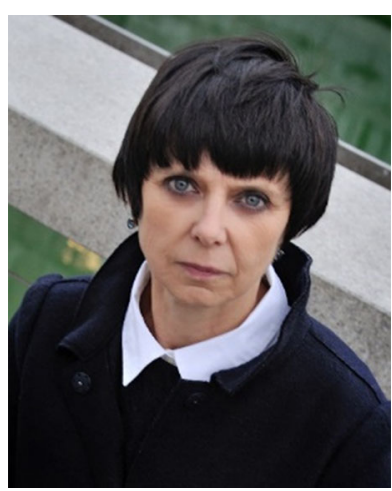

Prof. Ester Heath has been employed at Jožef Stefan Institute since 1991. She earned her M.Sc. (1994) and Ph.D. (1998) in ChemistryEnvironmental Organic Analysis from the University of Ljubljana, Ljubljana, Slovenia. She spent 15 months at the University of Plymouth, Plymouth, in the UK and two years at McGill University, Montreal, QC, Canada. Currently, Prof. Heath is Head of the Laboratory for Organic Analytical Chemistry within the Department of Environmental Sciences, Jožef Stefan Institute, and a full professor at the International Postgraduate School Jožef Stefan in Ljubljana, Slovenia. Prof. Heath has been working in the field of organic analytical chemistry for over 25 years and has a broad experience in experimental work (sample preparation, quantitative and qualitative determination) and analyzing trace organic compounds and their metabolites/transformation products using different analytical techniques (gas/liquid chromatography, mass spectrometry). Lately, she has been involved in studying the cycling of organic contaminant residues in matrices related to the environment, food, and health. Prof. Heath is a Member of the European Chemical Societies' Division of Chemistry and the Environment and an associate editor of ESPR.

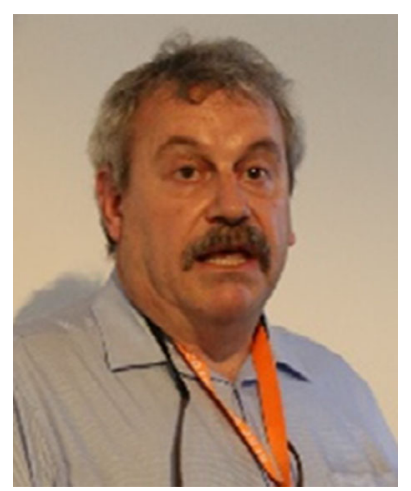

Dr. Roland Kallenborn is a university Professor in the field of organic analytical chemistry, environmental chemistry and environmental risk assessment, bioaccumulation, and food web responses to environmental contaminants. Kallenborn was appointed Professor competence by an independent international evaluation committee in 2007. $\mathrm{He}$ is an environmental chemist with his main research interests in method development for identification, characterization, and mitigation of organic environmental pollutants (including contaminants of emerging concern and transformation products). Currently, his research focuses on the elucidation of pollutant profiles in Urban Agriculture, food processing, and Arctic environments. He applies modern trace analytical methods in an interdisciplinary context in his research strategies. For his research, he applies quantitative validated analytical methods for the determination of legacy and new priority anthropogenic pollutant. He works with advanced chromatographic separation techniques with sensitive mass spectrometric detection (LC/MS, GC/MS, GCxGC-MS). Kallenborn is author/co-author of 110 per reviewer publications, 12 books/monographs (author, chapter author, and editor), 20 contract reports, 10 popular science papers, and more than 250 presentations (poster/ oral) in international conferences and seminars. He serves as editor/editorial board member for the IF-registered scientific Journals "Current Chromatography," "Fresenius Environmental Bulletin," "Ecotoxicology and Chemistry," "Environmental Science and Pollution Research" (Springer), and "Chemosphere" (Elsevier).

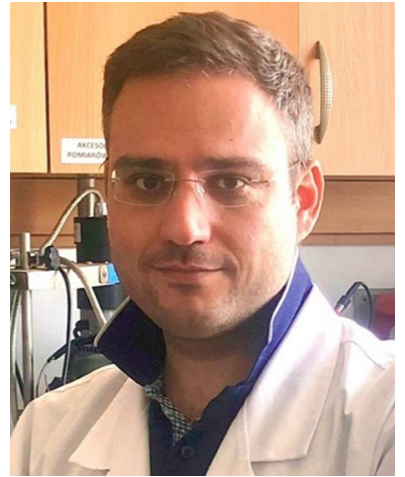

D r. D i m it rios A. Giannakoudakis received his Ph.D. degree at the City University of New York (CUNY) in the subdiscipline of nanotechnology and materials chemistry in 2017. Then, he continued as a postdoctoral researcher and adjunct tutor at the City College of New York (CCNY), at Aristotle University of Thessaloniki (AUTh), and at the Institute of Physical Chemistry of Polish Academy of Sciences (IChF) in Warsaw. Currently, he serves as assistant professor at the IChF. His research interest focuses on photo/thermo/sonocatalysis (solely or in combination) in diverse environmental and energy applications and on design, functionalization, and physicochemical features characterization of nanoengineered materials/nanocomposites. He has coauthored more than 72 papers in leading journals, four book, and two invention patents, and he serves in the editorial board of two journals and as guest editor of nine journal special issues (www.DaGchem.com). 


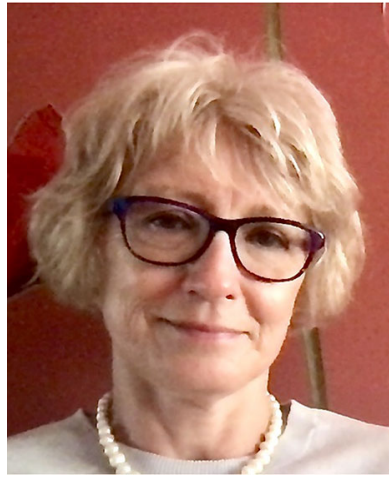

Prof. Teresa J. Bandosz is a full professor of Chemistry and Chemical Engineering at the City College of New York (Ph.D. In Chemical Engineering (Krakow Polytechnic); D.Sci. in Physical Chemistry (Maria CurieSklodowska University). She has a broad experience in the field of materials preparation, and their applications to environmental problems related to the development of adsorbents for gas separation. For three years, she was associated with Dalian University of Technology in China as a sky scholar/guest professor of Chemical Engineering. Dr. Bandosz is a Fulbright Senior Scholar, the Fellow of the Japan Society for the Promotion of Science, and Fellow of the American Carbon Society and the American Carbon Society Graffin Lecturer in Carbon Science and Technology. She edited the book "Activated carbon surface in environmental remediation," published by Elsevier (2006) and coauthored "Detoxification of Chemical Warfare Agents: From WWI to Multifunctional Nanocomposite Approaches" published in 2018. Her work during last 30 years has resulted in 7 US patents and over 420 publications in peer-reviewed journals. Her recent research interests include synthesis of graphene/MOF, graphene/hydroxide composites for separation and energy harvesting applications, visible light photoactivity of carbonaceous materials, energy storage, oxygen reduction catalysts, and $\mathrm{CO}_{2}$ sequestration and reduction. She is a coeditor of Journal of Colloid and Interface Science and also serves on the Editorial Boards of Carbon, C; Adsorption Science and Technology; and Chemical Engineering Journal and Applied Surface Science. She was on the Advisory Board of American Carbon Society, on the Board of Directors of International Adsorption Society. Her Hirsh Index is 72 (excluding self-citations).

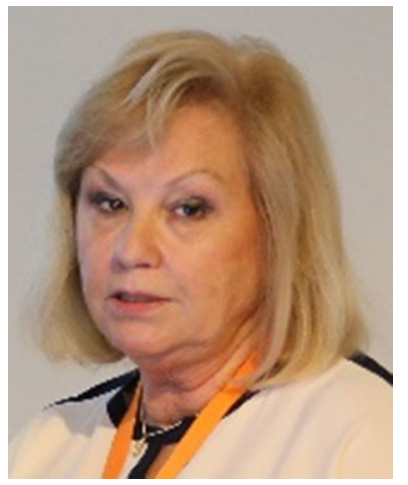

Prof. Eleni Deliyanni is a full professor of chemical technology at the department of Chemistry of Aristotle University of Thessaloniki. In her career, she has published more than 80 research papers which have attracted up to now more than 4500 citations with an h-index of 37 (google scholar). She is the president of the Chemical Association of Northern Greece. She has organized or been in the organizing committee of several national and international conferences and webinars and has been invited to give multiple lectures in International Conferences and Advanced schools worldwide. In 2020, she was included in the $2 \%$ top world scientists in the field of Environmental Technology (for the year 2019), which was published in PLOS Biology based on Scopus database.

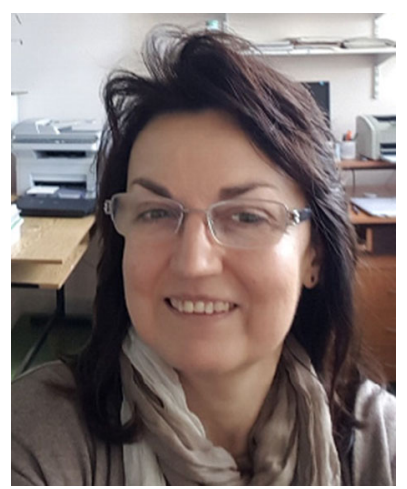

Prof. Slavica Ražić graduated from the University of Belgrade, Faculty of Pharmacy, from which she obtained the MS degree, and $\mathrm{PhD}$ accomplished at the Faculty of Chemistry-Department of analytical chemistry (2000). Since 2012, Slavica Ražić is a full professor in the Department of Analytical Chemistry of the Faculty of Pharmacy-University of Belgrade. She served as the Head of the Institute of Analytical Chemistry (20032007). In 2014, she accomplished the Specialist Academic Studies at the Faculty of Pharmacy on Toxicological risk assessment for environmental pollutants. The main research interests of Prof. Ražić lie in the analytics of environmental and biological samples, in method development for analysis, and monitoring of trace and minor elements and bioactive organic compounds, with the following topics: (i) elucidation of the bioavailability, mobility, distribution and accumulation of elemental species in different environmental compartment with their impact on human health (F-AAS, F-AES, GF-AAS, ICP-AES, and ICP-MS), (ii) analysis of bioactive organic compounds in plants important in pharmaceutical and forensic sciences (GCMS, HPLC, LC-MS, FTIR, TLC,...), (iii) greener sample preparation and applications. Since 2002, Prof. S. Ražić has chaired the Division of the Analytical Chemistry of the Serbian Chemical Society (SCS), acting also as a representative in the Division of Analytical Chemistry of the European Chemical Society (DAC-EuChemS). She started her term as Chairperson of the DAC-EuChemS in 2017. In a period 2012-2016, she served as the Vice-President of the Serbian Chemical Society (SCS) and from 2013 Slavica is acting as official representative of the SCS in the IUPAC, being also a member of its Analytical Chemistry Division from 2016 to 2017. Slavica Ražić is elected to the EuCheMs Executive Board of European Chemical Society (EuChemS) https://www.euchems.eu/ about-us/executive-board/.

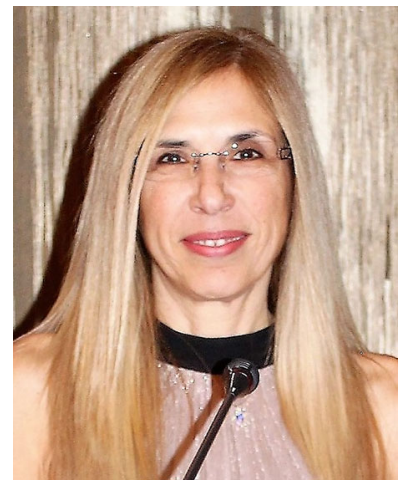

Dr. Victoria Samanidou is Full Professor and Director of the Laboratory of Analytical Chemistry in the Department of Chemistry of Aristotle University of Thessaloniki, Greece. Her research interests focus on the development of sample preparation methods using sorptive extraction prior to chromatographic analysis. She has co-authored 183 original research articles in peer reviewed journals and 57 reviews, 58 editorials/in view, and 50 chapters in scientific books (H-index 38 (Scopus Author ID 7003896015, 4847 citations, Web of Science Researcher ID AAE4121-2020). She is editorial board member of more than 27 scientific journals and guest editor in more than 24 special issues. She has peer reviewed more than 632 manuscripts for 135 scientific journals. In 2016, she was included in top 50 power list of women in Analytical Science, as proposed by Texere Publishers. https://theanalyticalscientist.com/power-list/the-power-list-2016. She is Leader of Working Group 1 Science and Fundamentals of EuChemS-DAC Sample Preparation Study Group and Network (2021). 


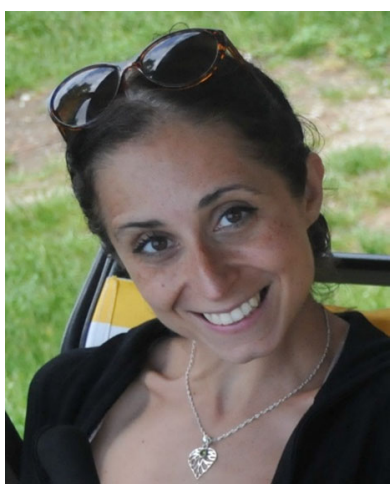

Prof. Ester Papa graduated in Biological Sciences in 2000 from the University of Insubria (Varese, Italy), where she also completed her $\mathrm{PhD}$ studies on the development of in silico models based on Quantitative Structure-Activity relationships (QSAR) for the prediction of persistent, bioaccumulative, and toxic behavior of chemicals from the molecular structure in 2006. In 2008, she became researcher and assistant professor at University of Insubria, and a visiting researcher in the Laboratoire ITODYS, CNRS-UMR 7086 at Universitè Paris Diderot (Paris, France) between 2014 and 2016, where she worked on the development and validation of QSARs for nanoparticles. Since 2017, she is an Associate Professor at the University of Insubria in the field of Environmental Chemistry and Chemometrics, where her research activity takes place at the Department of Theoretical and Applied Sciences (DiSTA). Since 2018, she leads the QSAR Research Unit in Environmental Chemistry and Ecotoxicology. Her research activities address the development, validation, and application of QSARs to predict toxicological and ecotoxicological endpoints for conventional and emerging pollutants, and industrial chemicals and nanoparticles. In addition, she is involved in the development of software for the development and application of QSARs (QSARINS and QSARINS-Chem standalone version software). She is currently involved in multiple international collaborations focused on the in silico prediction of toxicokinetic parameters and bioaccumulation to support the hazard and risk assessment in aquatic and terrestrial organisms. Prof. Ester Papa (H index: 32, Google Scholar) is the author or co-author of 1 book chapter and more than 60 papers in international peer review journals, which have received more than 3900 citations (Google Scholar).

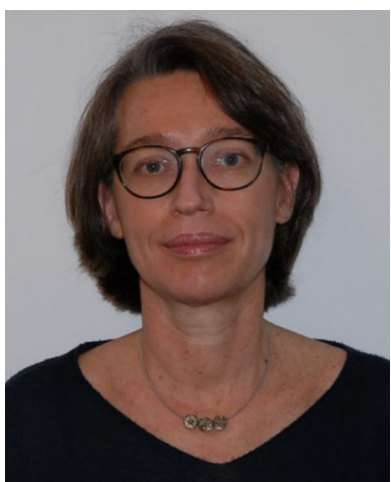

Prof. Silvia Lacorte (H-index 61) got her $\mathrm{PhD}$ in Analytical Chemistry in the University of Barcelona (1997), made a postdoc in Carso Centre d'Analyse (Lyon, France), and in 1999 became full researcher at the Department of Environmental Chemistry in IDAEA-CSIC. Nowadays, she is vice-director of the IDAEA-CSIC and leads an interdisciplinary research group in the field of analytical and environmental sciences. Dr. Lacorte is fellow of the Catalan Society of Chemistry (SCQ) of the Institute of Catalan Studies and of the Spanish
Society of Chromatography and Related Techniques (SECYTA). She is member of the Division of Environment of the EUCHEMS and member of the Scientific Council of the Rovaltain Foundation (France). Her main research interest is to evaluate the presence and impact of organic contaminants (including microplastics) in the environment and find solutions to mitigate the overwhelming problem of chemical pollution. Special effort is given to the protection of wildlife and natural resources. She has 220 articles published in SCI journals, several book chapters, and has presented her work in numerous conferences and congresses. She has been participating or coordinating national and international projects related to water pollution, impact of pollutants, and remediation actions and has supervised $15 \mathrm{PhD}$ students. S. Lacorte is member of the Gender Commission in IDAEA and for the last 10 years she has organized a workshop with the support of the Catalan Chemical Society on "Environment and Society" with only woman presenters as a way to promote and visualize their work.

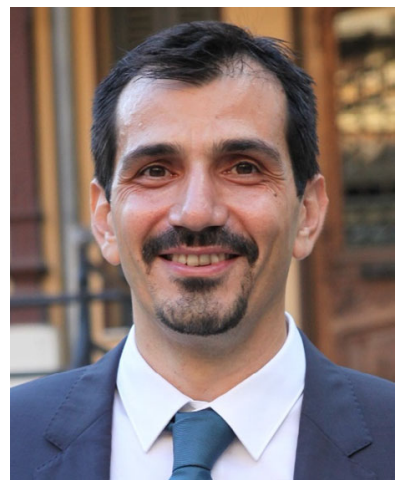

Dr. Athanasios Katsogiannis holds a chemistry degree and a $\mathrm{PhD}$ in environmental analytical chemistry from the Aristotle University of Thessaloniki, Greece, and has 18 years of professional experience gained through well-known European Institutions, including the Lancaster University and the Norwegian Institute for Air Research (NILU). As of $\mathrm{D}$ e c e mber 2013 , D r. Katsoyiannis works with the European Commission's Joint Research Centre (EC-JRC), Ispra, Italy. The areas of his scientific expertise span from the development and optimization of analytical chemistry techniques and sampling methodologies to the source understanding, occurrence, and fate of organic contaminants in all environmental compartments, including indoor air, atmospheric air, soil, water, and/or wastewater. Apart from the pure scientific understanding, his research approaches aim always at giving insight on the impact that organic compounds can have to the society and the health of organisms, food, and people. Dr. Katsogiannis has been long involved with the understanding of the presence and temporal trends of Persistent Organic Pollutants in remote zones (in particular the Arctic) and has contributed to the effectiveness evaluation of the Stockholm Convention for Persistent Organic Pollutants. Dr. Katsogiannis has authored/co-authored several papers and has also contributed to the publication of important scientific/policy reports on the aforementioned fields (Scopus Author ID: 15841853600). 


\section{Affiliations}

loannis A. Katsoyiannis ${ }^{1} \cdot$ Gerhard Lammel $^{2,3} \cdot$ Constantini Samara $^{4} \cdot$ Mathias Ernst $^{5} \cdot$ Jannis Wenk $^{6}$. Vincenzo Torretta ${ }^{7}$. Dimitra Voutsa ${ }^{2} \cdot$ Jes Vollertsen ${ }^{8} \cdot$ Thomas D. Bucheli $^{9} \cdot$ Levke Godbersen $^{9}$. Dimitra Lambropoulou ${ }^{2,10} \cdot$ Ester Heath $^{11} \cdot$ Roland Kallenborn $^{12} \cdot$ Dimitrios Giannakoudakis $^{13}$ • Eleni Deliyanni ${ }^{1}$. Teresa J. Bandosz ${ }^{14}$. Slavica Ražić ${ }^{15} \cdot$ Viktoria Samanidou $^{16} \cdot$ Ester Papa $^{7} \cdot$ Silvia Lacorte $^{17} \cdot$ Athanasios Katsoyiannis $^{18}$

1 Department of Chemistry, Laboratory of Chemical and Environmental Technology, Aristotle University of Thessaloniki, 54124 Thessaloniki, Greece

2 Max Planck Institute for Chemistry, Mainz, Germany

3 RECETOX, Masaryk University, Brno, Czech Republic

4 Department of Chemistry, Environmental Pollution Control Laboratory, Aristotle University of Thessaloniki, 541 24 Thessaloniki, Greece

5 TUHH, Institute for Water Resources and Water Supply (B-11), Am Schwarzenberg-Campus 3, Hamburg University of Technology, D27071 Hamburg, Germany

6 Department of Chemical Engineering and Water Innovation and Research Centre (WIRC@Bath), Claverton Down, Bath, Somerset, University of Bath, BA2 7AY, United Kingdom

7 Department of Theoretical and Applied Sciences, via GB Vico 46, Insubria University, I-21100 Varese, Italy

8 Department of The Built Environment, Thomas Manns Vej 23, Aalborg University, DK-9220 Aalborg Øst, Denmark

9 Environmental Analytics, Agroscope, Reckenholzstrasse 191, 8046 Zürich, Switzerland
10 Centre for Interdisciplinary Research and Innovation (CIRIAUTH), Balkan Center, 10th km Thessaloniki-Thermi Rd, GR 57001 Thessaloniki, Greece

11 Jožef Stefan Institute and International Postgraduate School Jožef Stefan, Jamova 39, 1000 Ljubljana, Slovenia

12 Faculty of Chemistry, Biotechnology and Food Sciences (IKBM), Norwegian University of Life Sciences (NMBU), NO1432 Ås, Norway

13 Institute of Physical Chemistry, Polish Academy of Sciences, Kasprzaka 44/52, 01-224 Warsaw, Poland

14 Department of Chemistry and Biochemistry, The City College of the City University of New York, NY 10031 New York, USA

15 University of Belgrade - Faculty of Pharmacy, Department of Analytical Chemistry, Belgrade, Serbia

16 Department of Chemistry, Laboratory of Analytical Chemistry, Aristotle University of Thessaloniki, GR 54124 Thessaloniki, Greece

17 Department of Environmental Chemistry, IDAEA-CSIC. Jordi Girona 18-26, 08034 Barcelona, Catalonia, Spain

18 European Commission, Joint Research Centre (JRC), Ispra, Italy 